JPPUMA: Jurnal Ilmu Pemerintahan dan Sosial PolitikUMA Uournal of Governance and Political Social UMA), 6 (2) (2018): 106-111, DOI: 10.31289/jppuma.v6i2.1617

JPPUMA: Jurnal Ilmu Pemerintahan dan Sosial Politik UMA (Journal of Governance and Political Social UMA)

Available online http://ojs.uma.ac.id/index.php/jppuma

\title{
Aceh Provincial Government's Food Security Policy to Facing Covid-19 Pandemic
}

\section{Syahnaz Oriza Keumala1), Eko Priyo Purnomo'1), Suswanta1) \& Paisal Akbar')}

1) Master of Government Affairs and Administration, Jusuf Kalla School of Government, Universitas Muhammadiyah Yogyakarta, Indonesia

2) Doctoral Program in Political Islam, Jusuf Kalla School of Government, Universitas Muhammadiyah Yogyakarta, Indonesia

Diterima: Juni 2018; Disetujui: Desember 2018; Dipublish: Desember 2018

\begin{abstract}
The Covid-19 pandemic has a significant impact on all aspects of life, especially in this case, its impact on food security conditions. With the imposition of restrictions on activities between regions to minimize the spread of Covid-19, we must put an acceptable food security policy to realize areas that are maintained in food conditions. The purpose of this research is to find out what food security policies the Aceh Provincial government is implementing in the face of the Covid-19 pandemic. The research method used is the qualitative method with a descriptive approach. The data obtained from online media reports are then processed using the Nvivo 12 Plus software to display Aceh Province's current policy issues. This study's findings indicate that the food security conditions of districts/cities in Aceh Province are still classified as green zones, meaning districts/cities in Aceh Province are still classified as healthy food security conditions.

Meanwhile, the policy issue present in Aceh Province shows that at the national reporting level, six problems arise, namely farmers, agriculture, health, food, programs, and governance. In contrast, there are issues on rice, farmer, community, government, food policy, program, land, and agriculture at the local level. Furthermore, carried out findings related to food security policies in Aceh province through two programs, namely the Aceh Food Independent Movement (Gampong) program and the Rice Planting Index Improvement Program, or what is known as the IP-300 program. This activity program has been carried out well by the city/district level government through various derivative programs that are in line with the objectives of the Aceh Province food security policy program.
\end{abstract}

Keywords: Policy, Food Security, Aceh Province

How to Cite: Syahnaz Oriza Keumala, Eko Priyo Purnomo, Suswanta \& Paisal Akbar, (2021). Aceh Provincial Government's Food Security Policy to Facing Covid-19 Pandemic. JPPUMA: Jurnal Ilmu Pemerintahan dan Sosial Politik UMA (Journal of Governance and Political Social UMA), 6 (2): 106-111 


\section{INTRODUCTION}

This study will analyze the policies of the Aceh Province government in maintaining food security during the Covid19 pandemic. The presence of the Covid-19 pandemic has had a significant impact on various aspects of life in the world. This pandemic created a health crisis that spread to almost all existing countries and disrupted economic growth in all affected areas (Anderson et al., 2020; Nasution et al, 2020). Regional quarantine policies and even state lockdowns from the activities of citizens between countries are some of the practical steps to tackle the spread of the Covid-19 virus (Lewnard \& Lo, 2020; Onder et al., 2020). This then impacts intercountry economic activities being disrupted, from export and import activities all experiencing a temporary suspension to minimize the spread of the Covid-19 virus.

The prohibition on exports and imports will affect the country's economic conditions and impact food security in several countries, where these countries depend on other countries to meet their basic food needs. A food crisis can happen in countries with food dependence on other countries if the pandemic does not subside. The lifting of export and import bans is not immediately carried out. As it is well known that food is a basic need for humans that must fulfill every day, then fulfilling the aspect of food adequacy for every human being is important (Masniadi et al., 2020). When talking about domestic Indonesia, food security is also a significant concern.
The condition of the territory of Indonesia, which is spread wide with many archipelagos and faced with different geographical conditions, causes the need for food security to have differences in each region.

This difference in food security conditions causes the need for each region to establish good relations in the context of cooperation in meeting regional markets, especially in this case, food availability. The food policy is made to ensure food security, including supply, diversification, safety, institutions, and food organization (Schaar, 2017). Good food policies are needed to increase food independence and food availability in all existing regions (Rivani, 2012; Wulandari et al., 2019); therefore, in the face of the Covid-19 pandemic, all areas in Indonesia must be able to present policies good food to ensure the availability of food in its territory, so that in fulfilling daily food needs can adequately provide it.

Food security policy is a form of public policy product, citing what was conveyed by Nugroho (2011), which defines public policy as "...all decisions made by the state, as a strategy to realize the state's goals. Public policy is a strategy to lead people initially, enter society in transition, and get to the community they aspire to. From the understanding of public policy, public policy is a strategy or design of steps made to achieve the goals to be obtained. The process of the presence of public policy products can then be seen in Figure 1 below.

Policy Process

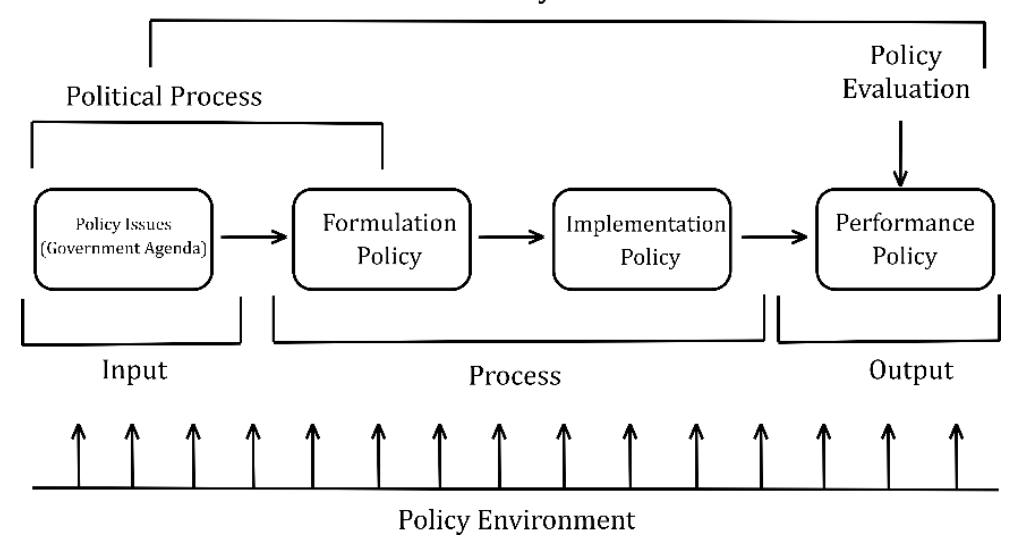


Government policy in fulfilling food security is one of the main things in realizing regions with a superior food security index. Food security is the relationship between three elements, namely the availability and stability of food; ease of obtaining food both physically and economically; and the use of food, which means that the food consumed must be sufficient, safe, and nutritious to meet energy needs to lead an active, healthy and productive life (Suryana, 2014). Food security occurs when people have physical and economic access to sufficient, safe, and nutritious food to meet their dietary needs and food preferences for an active and healthy life (Saliem et al., 2016). With the enactment of the Covid-19 pandemic national disaster emergency, causing human movement to be restricted, this directly impacts economic conditions and causally also affects regional food conditions (Masniadi et al., 2020). For this reason, responsive and effective policies are needed to fulfill regional food needs.

Previous studies related to local government policies in maintaining food security conditions have been carried out by Masniadi et al. (2020), who examined the food security condition of Sumbawa Regency in the face of the Covid-19 pandemic. This study found that Sumbawa Regency is facing an increasing number of states. Food insecure villages because the Food Hope Pattern (PPH) has not been achieved, and there are still villages in a priority category of food uncertain situations. Besides that, local government policies that can be a solution to food security during this pandemic are to utilize Local Staple Foods (P3L) in the form of food products that adapt regional characteristics based on local resources (Masniadi et al., 2020).

Janti, Martono, \& Subejo (2016), in their research, tried to see how far the local government of Bantul Regency in providing certainty of policy regulations regarding the protection of sustainable food agricultural land. The results of the research carried out show the lack of seriousness of the Bantul Regency government in supporting the creation of sustainable food agrarian land protection, and this is due to the discovery of various obstacles that occur, including immature spatial planning policies, violations of regional spatial planning regulations, farmers' willingness, interest groups, budget allocation for regulatory planning, as well as the availability of agricultural land (Janti et al., 2016).

Must also realize Food security policies by taking into account environmental insights. Khairina et al. (2020), in their research, explain that the role of local governments is very central in realizing environmental resilience through published policies, biological protection, and ecosystem functions are the key to the sustainability of ecological resilience, and this will also support the realization of regional food security. In addition, digital technology in the digital agricultural economy space can benefit the farming process, which can also help food security through the gifts received in terms of the ease of monitoring availability, access, and consumption (Wibowo, 2020).

Several previous studies have shown that must take local government policies supporting the realization of food security seriously. This is because existing policies have a direct effect on the food condition of the area. As one of the provinces located at the western end of Indonesia's territory in terms of food security, Aceh is very vulnerable if food distribution is hampered, as is known together with national food barns located in the islands of Java Sumatra and Sulawesi islands. Therefore, it is exciting to see how far the Aceh Province food security preparations deal with the Covid-19 pandemic situation and what 
policies the Aceh Government has presented to these problems.

For this reason, the difference in this research paper is that this research will try to see what policies have been carried out by the Aceh Provincial Government in maintaining food security during the Covid19 Pandemic. To make the discussion more accessible, the researcher will focus this research on several problem formulations, namely 1) What is the Condition of Food Security in Aceh Province?; 2) What policies did Aceh Province take in maintaining food security during the Covid-19 pandemic?

\section{RESEARCH METHOD}

The research method used in this study is a qualitative research method with a descriptive approach. Descriptive qualitative research aims to understand the conditions that occur in the field experienced by research subjects by describing these conditions descriptively in the form of a series of words and language by utilizing natural methods (P. Akbar et al., 2020; Moleong, 2008). For this reason, researchers use descriptive qualitative research methods to be more straightforward in describing the condition of food security and policies in Aceh Province. Aceh Province was chosen as the research location because geographically, Aceh Province is the westernmost region of the Unitary States of the Republic of Indonesia and is assumed to be an area that will directly feel a significant impact from restrictions on distribution activities carried out by the central government and local governments around Aceh Province to reduce the spread of the disease. Covid-19 virus.

In collecting research data, the authors obtained data from literature studies in the form of online media coverage, related websites, scientific articles of previous research, and government reports through the official websites of the Aceh Province local government. The data collection period from online media news is adjusted to the information available on each online media news portal that is the data source. The search is determined using keywords related to food conditions in Aceh Province. In the emphasis that this research is interpretive, interpretive is the researcher will try to emphasize the interpretation of the meaning of a prevailing social phenomenon, and this is done to focus on studying specific views on the research subject following the existing facts (Miles, Mattew B dan Huberman, 2009; Purwaningsih, 2015). The data obtained by the researchers were then carefully processed to describe the Aceh Government's policies on food security during the Covid-19 pandemic. Meanwhile, the news about food security obtained from online media news was then carefully processed by researchers using software from QSR International Nvivo 12 Plus through the N-Capture feature and then carefully coding it to bring up the data needed to look at food security policy issues in the Aceh region (Hutchisona et al., 2010; Johnston, 2006).

\section{RESULTS AND DISCUSSION \\ Conditions of Food Security and the Covid-19 Pandemic in Aceh Province}

Aceh is one of the provinces in the Unitary States of the Republic of Indonesia. The geographical location of Aceh Province is right at the western end of the Indonesian territory, precisely at the westernmost tip of the Sumatran archipelago. The total area of Aceh Province is 5,795,600 hectares, or $3.02 \%$ of the total area of Indonesia as a whole (BPS Provinsi Aceh, 2020b). The climate characteristics of Aceh Province have a tropical climate, which is due to the location of the Aceh region, which is near the equator. The average temperature in Aceh during the 2019 period was recorded at 25.5-28.5 degrees Celsius. In the 20182019 period, the population growth rate of Aceh Province reached 1.71\%; this population growth rate decreased when 
Syahnaz Oriza Keumala, Eko Priyo Purnomo, Suswanta, Paisal Akbar, Aceh Provincial Government's Food Security Policy to Facing Covid-19 Pandemic

compared to the 2017-2018 period, which gained 1.77\% (BPS Provinsi Aceh, 2020a).

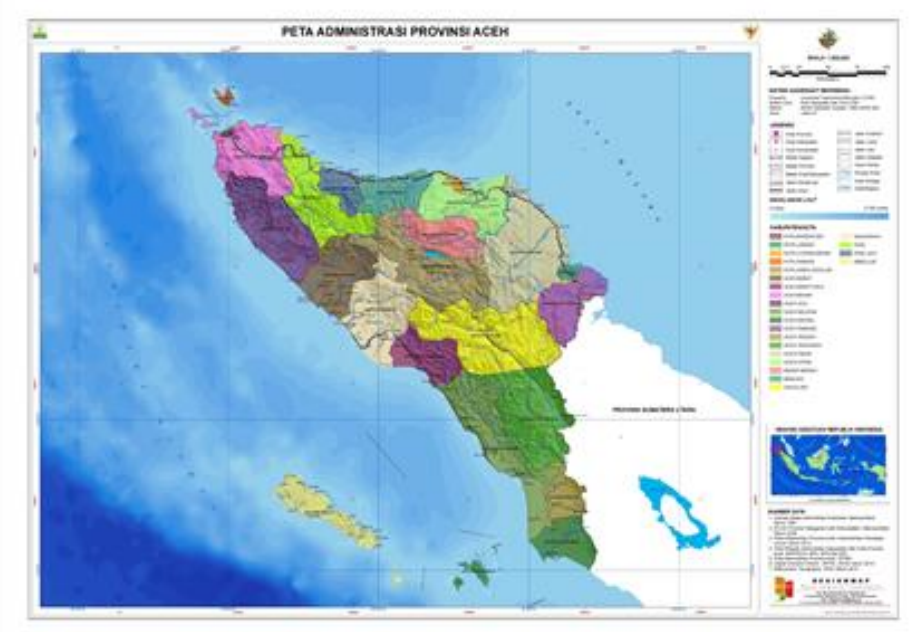

Figure 2. Aceh Province Administrative Map Source: Petatematikindo, (2013)

With an area of 5.7 million hectares, Aceh Province has 24 districts/cities, 289 sub-districts, and 6,516 kampongs (the Acehnese name for villages). In Table 1, the development of the expansion of the camping area can be seen during the 20172019 period, where there was an increase in the number of gampongs in as many as seven villages. This shows the regional expansion that occurs in Aceh Province, the regional development that occurs is usually based on the desire to be able to create the independence of a region so that it can increase the effectiveness of public services and streamline development in an area (S. Akbar, 2018; Muqoyyidin, 2013).

Table 1. Number of Districts/Cities, Sub Districts, and Gampongs in Aceh Province

\begin{tabular}{clcccccc}
\hline \multirow{2}{*}{ No } & \multicolumn{2}{c}{ Districts/City } & \multicolumn{3}{c}{ Sub Districts } & \multicolumn{3}{c}{ Village } \\
\cline { 3 - 8 } & & $\mathbf{2 0 1 9}$ & $\mathbf{2 0 1 8}$ & $\mathbf{2 0 1 7}$ & $\mathbf{2 0 1 9}$ & $\mathbf{2 0 1 8}$ & $\mathbf{2 0 1 7}$ \\
\hline 1 & Simeulue & 10 & 10 & 10 & 138 & 138 & 138 \\
\hline 2 & Aceh Singkil & 11 & 11 & 11 & 120 & 120 & 120 \\
\hline 3 & Aceh Selatan & 18 & 18 & 18 & 260 & 260 & 260 \\
\hline 4 & Aceh Tenggara & 16 & 16 & 16 & 385 & 385 & 385 \\
\hline 5 & Aceh Timur & 24 & 24 & 24 & 515 & 515 & 515 \\
\hline 6 & Aceh Tengah & 14 & 14 & 14 & 295 & 295 & 295 \\
\hline 7 & Aceh Barat & 12 & 12 & 12 & 321 & 321 & 321 \\
\hline 8 & Aceh Besar & 23 & 23 & 23 & 604 & 604 & 604 \\
\hline 9 & Pidie & 23 & 23 & 23 & 731 & 731 & 731 \\
\hline 10 & Bireuen & 17 & 17 & 17 & 609 & 609 & 609 \\
\hline 12 & Aceh Utara & 27 & 27 & 27 & 852 & 852 & 852 \\
\hline 13 & Aceh Barat Daya & 9 & 9 & 9 & 152 & 152 & 152 \\
\hline 14 & Gayo Lues & 11 & 11 & 11 & 148 & 148 & 148 \\
\hline 15 & Aceh Tamiang & 12 & 12 & 12 & 213 & 213 & 213 \\
\hline 16 & Nagan Raya & 10 & 10 & 10 & 222 & 222 & 222 \\
\hline 17 & Aceh Jaya & 9 & 9 & 9 & 172 & 172 & 172 \\
\hline 18 & Bener Meriah & 10 & 10 & 10 & 233 & 233 & 233 \\
\hline 19 & Pidie Jaya & 8 & 8 & 8 & 222 & 222 & 222 \\
\hline 20 & Banda Aceh & 9 & 9 & 9 & 90 & 90 & 90 \\
\hline 21 & Sabang & 2 & 2 & 2 & 18 & 18 & 18 \\
\hline 22 & Langsa & 5 & 5 & 5 & 66 & 66 & 66 \\
\hline 23 & Lhokseumawe & 4 & 4 & 4 & 68 & 68 & 68 \\
\hline 24 & Subulussalam & 5 & 5 & 82 & 82 & 82 \\
\hline & & 5 & & & & & \\
\hline
\end{tabular}




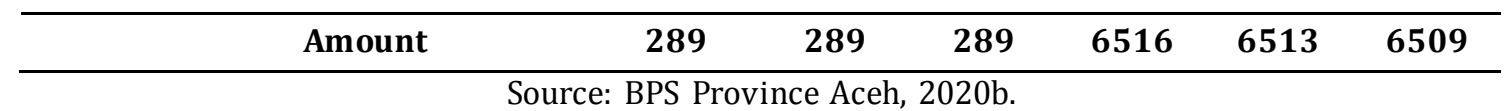

As an area that has a tropical climate, Aceh Province has quite good agricultural conditions. This is shown by making the farm sector one of the mainstay sectors of Aceh Province in developing the economy; based on the 2019 Aceh Province Gross Regional Domestic Product (GRDP) data, the most significant contribution to GRDP revenue is obtained from the agricultural business field (BPS Provinsi Aceh, 2020c). Usmaliadanti (2011) revealed that one of the main strategies of food security is to increase the power of agricultural technology and the distribution of inclusive agrarian technology throughout the region, with the increase and diffusion of agricultural technology, is expected to increase food production and food distribution at the regional level (Pramono, 2014).

The condition of food security in Aceh Province can be seen in Figure 2. Based on food security index data from 2018 to 2020, the Regency/City which has the highest food security index is occupied by the City of Banda Aceh with an index score in 2020 of 85.32, an increase of 2.37 points compared to with an index score in 2018. From the visualization of existing data in 2020 , it can be seen that almost all districts/cities in Aceh Province have been classified as the 3rd, 4th, 5th, and 5th Food Security Index (IKP) groups. 6. This IKP Cut Off Point grouping shows that the Regency/City in Aceh Province has been classified as a green area, which means that the site is food-insecure.

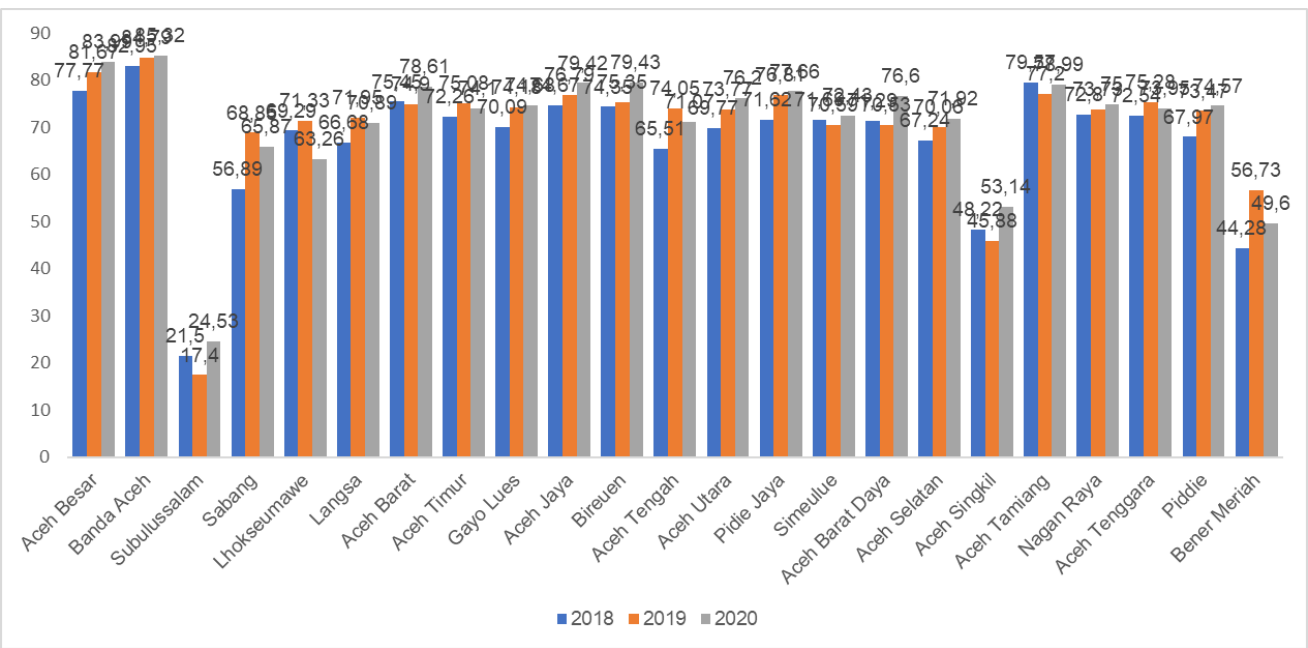

Source: Food Security Agency2018, 2020, 2021

Figure 3. District/City Food Security Index in Aceh Province.

However, even though most regencies/cities in Aceh Province occupy the green zone, there are still two regions with a food security index level in the red area or are vulnerable to food insecurity, namely Subulussalam City and Aceh Singkil Regency. Aceh to be able to build these two regions towards a substantial condition of food security. 


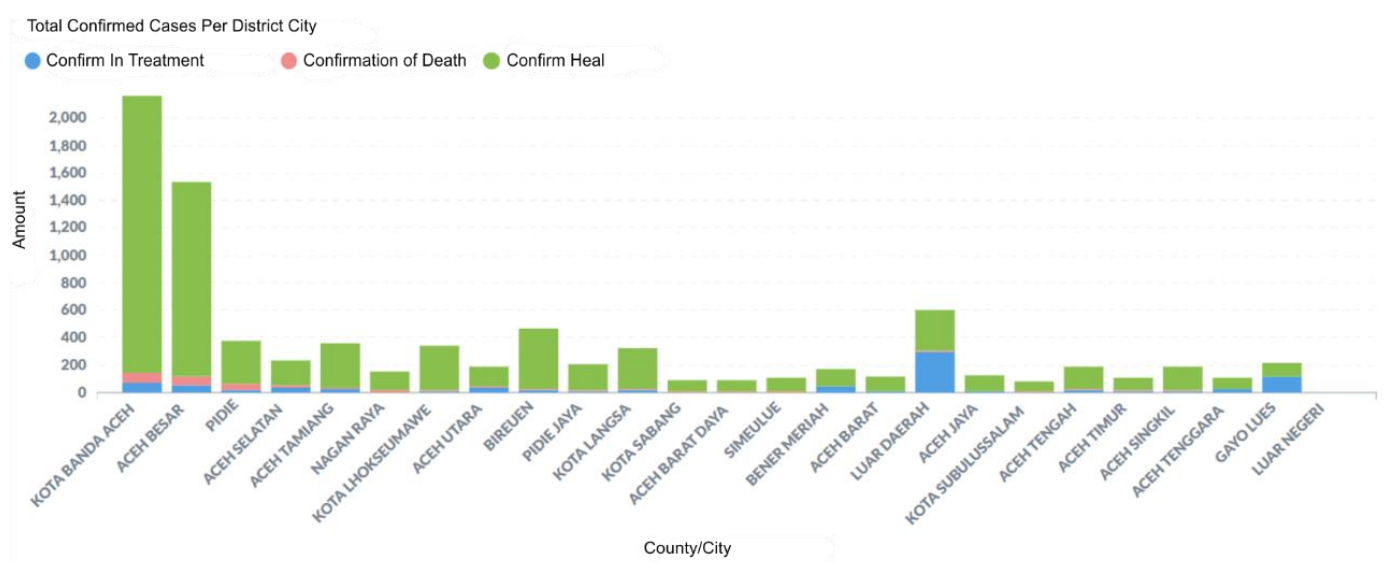

Source: Aceh Disaster Management Agency, 2020.

Figure 4. Total Confirmed Cases of Covid-19 in Aceh Province

Aceh Province is currently confirmed in the face of the Covid-19 Pandemic (Satgas Penanganan Covid-19, 2020). Based on the latest update on December 13, 2020, the status of confirmed cases in Aceh Province reached 8,522 points, with 7345 recovered patients, 839 people being treated, and 338 people who died (Badan Penanggulangan Bencana Aceh, 2020).

Figure 3 above shows the level of distribution of Covid-19 in 23 districts/cities in Aceh Province; based on the graph shown above, Banda Aceh City is the area that has the most cases of Covid-19 with confirmed patients recovering 2,025 cases, confirmed deaths, 69 cases, and confirmation in treatment as many as 71 cases. Furthermore, Aceh Besar District became the second area in Aceh with the highest Covid-19 cases, namely 1,421 cases confirmed to be cured, 63 points confirmed dead, and 53 cases under treatment.

\section{Aceh Province Food Security Policy Issues}

The need for food security development in each region is undoubtedly different; for this reason, it is necessary to have an initial reading of an issue that occurs in the field related to the actual condition of food security in a region. Reading an issue present in the community will make it easier for policymakers to formulate a policy and determine the goals to be achieved.

To find out the food security issues that occur in Aceh Province, the authors try to collect data through reports on several online media news portals on a national and local scale to provide a complete picture regarding what food security issues are currently happening in the Aceh region. For this reason, the authors classify several online media news portals as references as follows:

Table 2. National and Local Online Media News Portals

\begin{tabular}{cccccc}
\hline & National Media & & \multicolumn{2}{c}{ Local Media } \\
\hline Name & Link & Amount & Name & Link & Amount \\
\hline Kompas.com & $\begin{array}{c}\text { https://www.kompa } \\
\text { s.com/ }\end{array}$ & 12 & $\begin{array}{c}\text { Aceh Journal } \\
\text { National Network } \\
\text { (AJNN) }\end{array}$ & $\begin{array}{c}\text { https://www.aj } \\
\text { nn.net/ }\end{array}$ & 15 \\
\hline Detik.com & $\begin{array}{c}\text { https://www.detik.c } \\
\text { om/ }\end{array}$ & 7 & $\begin{array}{c}\text { Aceh.Tribunnews. } \\
\text { com }\end{array}$ & $\begin{array}{c}\text { https://aceh.tri } \\
\text { bunnews.com/ }\end{array}$ & 22 \\
\hline AntaraNews.com & $\begin{array}{c}\text { https://www.antara } \\
\text { news.com/ }\end{array}$ & 11 & Acehportal.com & $\begin{array}{c}\text { https://www.a } \\
\text { cehportal.com/ }\end{array}$ & 29 \\
\hline Okezone.com & $\begin{array}{c}\text { https://www.okezon } \\
\text { e.com/ }\end{array}$ & 6 & AntaraAceh & $\begin{array}{c}\text { https://aceh.an } \\
\text { taranews.com/ }\end{array}$ & 29 \\
\hline
\end{tabular}

Source: Processed by the author. 
Online media news portals are one of the information media that can provide convenience in disseminating news information. Based on table 2, the data obtained through online media coverage is related to the keyword "Aceh Food Security" for the national media group and
"Food Security" for the local media group; after searching with these two keywords, I found several news related news. Food security in Aceh Province. If viewed more closely, Aceh's food security discussions are reported mainly by local online news media in Aceh Province.

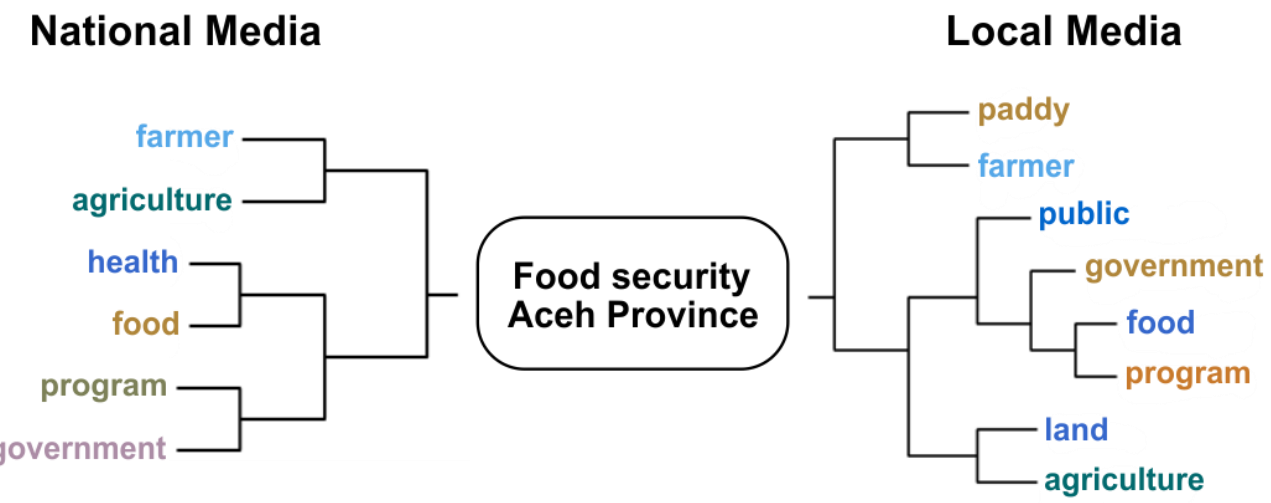

Source: Cluster Analysis Tools Nvivo 12 Plus Figure 5. Policy Issues that appear in Food Security News in National Media and Local Media.

The data processing of national and local online media reports using the Nvivo 12 Plus qualitative data processing application shows several policy issues that are the topics of discussion in the news about food security in Aceh Province. Six problems appear in the information from the national reporting level, namely farmers, agriculture, health, food, programs, and government. Each policy issue has a relationship between one policy issue and another; this can be seen from the interconnected chart between farmer policy issues and agricultural policy issues. In addition, four other policy issues also show interrelated relations, namely health policy issues directly related to food policy issues and program policy issues that are directly related to government policy issues.

The data processing of national and local online media reports using the Nvivo 12 Plus qualitative data processing application shows several policy issues that are the topics of discussion in the news about food security in Aceh Province. Six problems appear in the information from the national reporting level, namely farmers, agriculture, health, food, programs, and government. Each policy issue has a relationship between one policy issue and another, and this can be seen from the interconnected chart between farmer policy issues and agricultural policy issues. In addition, four other policy issues also show interrelated relations, namely health policy issues directly related to food policy issues and program policy issues that are directly related to government policy issues.

All of the policy issues that emerged from the national and local online media coverage above show that several issues related to food security should be the primary concern of the Aceh Provincial Government. The Aceh Provincial Government must present policies that can cover directly associated problems that occur in the field. Figure 4 also shows the relationship between one approach and another, meaning that if the Aceh Government wants to solve one of the issues that are present today, it must also pay attention to other interrelated issues. Nugroho, (2011) revealing policy issues will later move the government in 
formulating public policies to solve problems.

\section{Aceh Province Food Security Policy}

Nationally, the priority of food security development in 2020 is to improve food quality and safety, and this is under the transformation of the policy into the direction of the Aceh Medium Term Development (PJMA) policy to realize one of the 2017-2022 Aceh Government Missions, namely "Guarantee Sovereignty and Food Security with Implications for the Welfare of Farmers and Fishermen through Increased Productivity and Added Value of
Agricultural and Marine Products" (Dinas Pangan Aceh, 2019).

Through the Aceh Food Service (2019), the Aceh Provincial Government has formulated a mandatory affairs program carried out with the Aceh Apparatus Work Unit (SKPA) to increase the food security index for all regions in Aceh. The program of compulsory affairs is divided into three, namely the Program for Increasing Food Access, the Program for Improving the Quality of Consumption and Food Security, and the Program for Planning for Economic Development. More details can be seen in Table 2 below.

Table 3. Program for Compulsory Affairs for the Aceh Food Service

\begin{tabular}{|c|c|c|c|}
\hline No & Program & & Activity \\
\hline 1 & $\begin{array}{l}\text { Program Improvement Food } \\
\text { Access }\end{array}$ & $\begin{array}{l}\text { a) } \\
\text { b) } \\
\text { c) } \\
\text { d) } \\
\text { e) } \\
\text { f) } \\
\text { g) } \\
\text { h) } \\
\text { i) }\end{array}$ & $\begin{array}{l}\text { Development of Food Potential and Resources } \\
\text { Construction of Food Barns and Drying Floors } \\
\text { Effect of Food Independent Areas } \\
\text { Handling of Food Insecure Areas } \\
\text { Handling of Transient Food Insecurity } \\
\text { Preparation of Food Availability Analysis } \\
\text { Management of Regional Food Reserves } \\
\text { Monitoring and Analysis of Food Price Access } \\
\text { strengthening LPDM and PUPM }\end{array}$ \\
\hline 2 & $\begin{array}{l}\text { Program to Improve } \\
\text { Consumption Quality and Food } \\
\text { Safety }\end{array}$ & $\begin{array}{l}\text { a) } \\
\text { b) } \\
\text { c) } \\
\text { d) } \\
\text { e) } \\
\text { f) }\end{array}$ & $\begin{array}{l}\text { Development of Utilization and Introduction of } \\
\text { B2SA Food Consumption } \\
\text { Development of Community Food } \\
\text { Diversification } \\
\text { Formulation of Analysis of Food Consumption } \\
\text { Patterns and Needs } \\
\text { Development of the Quality and Safety of Food } \\
\text { Cooperation and Regional Food Safety } \\
\text { Information } \\
\text { Development of Certification and Monitoring } \\
\text { of Maximum Residue Limits on PSAT Products } \\
\text { Strengthening Institutional Capacity of Food } \\
\text { Safety Laboratory }\end{array}$ \\
\hline 3 & $\begin{array}{l}\text { Economic Development } \\
\text { Planning Program }\end{array}$ & $\begin{array}{l}\text { a) } \\
\text { b) } \\
\text { c) } \\
\text { d) }\end{array}$ & $\begin{array}{l}\text { Preparation of Food Security Development } \\
\text { Planning } \\
\text { Management of Food Development Data and } \\
\text { Information } \\
\text { Monitoring and Evaluation of Food } \\
\text { Development } \\
\text { Formulation of Regulations and Policy } \\
\text { Consolidation of the Food Security Council }\end{array}$ \\
\hline
\end{tabular}

Source: Aceh Food Service, 2019.

Then, the programs run by the Aceh Food Service and SKPA into various activities that could make the three programs of the Aceh Food Service's mandatory affairs successful. With the confirmation of Aceh Province as an area affected by the Covid-19 pandemic, the Aceh Provincial government must immediately make efforts to maintain the stability of strategic affairs in Aceh 
Province, both health stability and economy, and food security.

Based on data obtained from various food security policy issues in Aceh Province previously, one of the issues that become the main concern is the matter of food and programs, where food and programs in Aceh Province still need innovation and breakthroughs to maintain food stability in the region. Aceh. The condition of food security in Aceh Province, which is still classified as green, could have its safe status threatened if the impact of Covid on the movement of food distribution between regions continues to occur.

The Aceh Food Independent Movement (Gampang) is one of the food security policy programs presented by the Aceh Provincial government in 2020. Gampang is an effort by the Aceh Province government to improve Aceh Province food security and encourage the acceleration of handling the Covid-19 (DLHK Aceh, 2020a; kumparan.com, 2020; Setiyadi, 2020). In its implementation, the Acting Governor, $\mathrm{Mr}$. Nova Iriansyah, said that he carried out the Gampong program in a well-coordinated manner with all relevant stakeholder components, one example of the implementation of the Gampang program which involved various parties was the development of corn in the HTI concession area in collaboration with HIPAKAD Aceh with an area of arable land reaching 1,000 hectares. in Aceh Besar District (DLHK Aceh, 2020a, 2020b).

Quoting from DLHK Aceh (2020a), obtained the budget allocation for the Aceh Food Self-Sufficiency Program from the distribution of financial stimulus assistance worth 300 billion, which was earmarked for districts/cities to build improved health facilities, economic impact, limited supervision, and the Gampang program, from $40 \%$ of the budget allocation is for the Aceh Food Independent Movement and the response to the economic impact of the Covid-19 pandemic.
Several regencies/cities in Aceh Province have started to carry out various food improvement activities to make the Aceh Food Independent Movement a success, in Bener Meriah Regency, for example, the planting of multiple types of superior plants in each resident's house to provide food independence to each family so that they can have good food availability (InfoPublik, 2020; Serambinews.com, 2020). Furthermore, West Aceh Regency is also actively committed to the success of the Food Independent Aceh Movement. This is shown by various planting and developing activities for vegetable and agricultural rice commodities during the pandemic (Pemerintah Kab. Aceh Barat, 2020; rri.co.id, 2020).

Central Aceh District did not want to be left behind. To realize the Aceh Food Independent Movement (Gampang), the Central Aceh District government then transformed the program into two programs, namely the Sustainable Food Garden (P2L) program and Food Independent Area (KMP) (Humans Aceh Tengah, 2020). Meanwhile, the Pidie Jaya Regency government, to maintain its food security, also plans to issue a regional-level regulatory policy that regulates the Qanun on Sustainable Food Agricultural Land. This regulation was made to protect the conversion of agricultural land (Muksalmina, 2020).

The Aceh Food Independent Movement Program is an effort that is in line with the various mandatory business programs in the Aceh Provincial Food Service in dealing with the Covid-19 pandemic situation that threatens food security. This program can genuinely answer the problems that occur in the field is needed. In addition to the Aceh Food Independent Movement program, in 2020, the Aceh provincial government also implemented a program to increase the rice planting index three times a year or the IP300 program. This program is run in several districts that have become the 
Syahnaz Oriza Keumala, Eko Priyo Purnomo, Suswanta, Paisal Akbar, Aceh Provincial Government's Food Security Policy to Facing Covid-19 Pandemic

regional rice granaries of Aceh Province, namely Aceh Regency. Besar, Southwest Aceh Regency, North Aceh Regency, and Pidie Jaya Regency (Pemprov Aceh, 2020).

The Province of Aceh's programs has shown various efforts to strengthen food security in the province. In addition to efforts to overcome the Covid-19 pandemic in 2020, food has become the primary concern of the Aceh provincial government. The presence of a good food security policy is the main thing that must attend to in maintaining the food security index of a region (Dako et al., 2019; Rivani, 2012; Wulandari et al., 2019).

\section{CONCLUSION}

The condition of food security in Aceh Province, although the majority of the Regencies/Cities in it have occupied the Green Food Security Index Cut Off Points, there are still two regions that have a food security index that is classified as a red zone, namely Subulussalam City and Aceh Singkil Regency. Based on the results of online media reporting data shows several policy issues that have emerged, namely in national media news covering farmer matters policy, agriculture, health, food, programs, and government and local media covering rice policy matters, farmers, communities, government, food, programs, land, and agriculture. The Aceh Province government's food security policy programs carried out during the Covid-19 pandemic are the Aceh Food Independent Movement (Gampang) and the Rice Planting Index Program, commonly referred to as IP-300. This activity program has been carried out well by the city/district level government through various derivative programs that are in line with the objectives of the Aceh Province food security policy program.

\section{BIBLIOGRAPHY}

Akbar, P., Pribadi, U., \& Purnomo, E. P. (2020). Faktor-Faktor yang Mempengaruhi Kinerja Pegawai dalam Penerapan Sidalih di Komisi Pemilihan Umum Daerah Istimewa
Yogyakarta. Analitika: Jurnal Magister Psikologi UMA, 12(1), 1-9.

Akbar, S. (2018). Analisa Masalah-Masalah yang Muncul Dalam Pemekaran Wilayah Baru Pada Penyelengaraan Otonomi Daerah. 3(1), 1-15.

Anderson, M., Mckee, M., \& Mossialos, E. (2020). Developing a sustainable exit strategy for COVID-19: health, economic and public policy implications. Journal of the Royal Society of Medicine, 113(5), 176-178. https://doi.org/10.1177/014107682092522 9

Badan Penanggulangan Bencana Aceh. (2020). Statistik Covid-19 Aceh. Covid19.Acehprov.Go.Id. https://covid19.acehprov.go.id/

BPS Provinsi Aceh. (2020a). Master File Wilayah Provinsi Aceh 2015-2020. https://aceh.bps.go.id/indicator/153/200/1 /banyaknya-wilayah.html

BPS Provinsi Aceh. (2020b). Statistik Daerah Provinsi Aceh.

BPS Provinsi Aceh. (2020c). Statistik Keuangan Pemerintah Daerah Provinsi Aceh 2018-2019.

Dako, F. X., Purwanto, R. H., Faida, L. R. W., \& Sumardi, S. S. (2019). Tipologi Pola Konsumsi Pangan Untuk Menjaga Ketahanan Pangan Masyarakat Sekitar Kawasan Hutan Lindung Mutis Timau KPH Kabupaten Timor Tengah Selatan. Jurnal Ketahanan Nasional, 25(1), 92. https://doi.org/10.22146/jkn.39544

Dinas Pangan Aceh. (2019). Rencana Kerja (RENJA) Tahun 2020. In Dinas Pangan Aceh.

DLHK Aceh. (2020a). Pemerintah Aceh Sosialisasikan Gerakan Aceh Aman Pangan (Gampang) Kepada Seluruh Kabupaten/Kota. Dlhk.Acehprov.Go.Id.

http://dlhk.acehprov.go.id/2020/08/pemeri ntah-aceh-sosialisasikan-gerakan-acehaman-pangan-gampang-kepada-seluruhkabupaten-kota/

DLHK Aceh. (2020b). Plt Gubernur Aceh Canangkan “GAMPANG" Untuk Antisipasi Dampak Covid19. Dlhk.Acehprov.Go.Id. https://dlhk.acehprov.go.id/2020/07/pltgubernur-aceh-canangkan-gampang-untukantisipasi-dampak-covid-19/

Humas Aceh Tengah. (2020). Aceh Tengah Maksimalkan Program P2L Dan KMP. Humas.Acehtengahkab.Go.Id. http://humas.acehtengahkab.go.id/acehtengah-maksimalkan-program-pekaranganpangan-lestari-dan-kawansan-mandiripangan/

Hutchisona, A. J., Johnstonb, L. H., \& Breckona, J. D. (2010). Using QSR-NVivo to facilitate the development of a grounded theory project: An account of a worked example. International Journal of Social Research 
JPPUMA: Jurnal Ilmu Pemerintahan dan Sosial Politik UMA (Journal of Governance and Political Social UMA), 6 (2) (2018): 106-111 $\begin{array}{lcc}\text { Methodology, } & 13(4), & 283-302 \\ \text { https://doi.org/10.1080/136455709029963 }\end{array}$ 01

InfoPublik. (2020). Pemprov Aceh Berupaya Tingkatkan Ketahanan Pangan. Infopublik.Id. http://infopublik.id/kategori/nusantara/46 6367/pemprov-aceh-berupaya-tingkatkanketahanan-pangan

Janti, G. I., Martono, E., \& Subejo, S. (2016). Perlindungan Lahan Pertanian Pangan Berkelanjutan Guna Memperkokoh Ketahanan Pangan Wilayah (Studi di Kabupaten Bantul, Daerah Istimewa Yogyakarta). Jurnal Ketahanan Nasional, 22(1), $1-21$. https://doi.org/10.22146/jkn.16666

Johnston, L. (2006). Software and method: Reflections on teaching and using QSR NVivo in doctoral research. International Journal of Social Research Methodology, 9(5), 379-391. https://doi.org/10.1080/136455706006594 33

Khairina, E., Purnomo, E. P., \& Malawnai, A. D. (2020). Sustainable Development Goals: Kebijakan Berwawasan Lingkungan Guna Menjaga Ketahanan Lingkungan Di Kabupaten Bantul Daerah Istimewa Yogyakarta. Jurnal Ketahanan Nasional, 26(2), 155 https://doi.org/10.22146/jkn.52969

kumparan.com. (2020). Strategi Pemerintah Aceh Jaga Ketahanan Pangan di Masa Pandemi COVID-19. Kumparan.Com. https://kumparan.com/acehkini/strategipemerintah-aceh-jaga-ketahanan-pangan-dimasa-pandemi-covid-19-1tll1H6JbDT/full

Lewnard, J. A., \& Lo, N. C. (2020). Scientific and ethical basis for social-distancing interventions against COVID-19. The Lancet Infectious Diseases, 20(6), 631-633. https://doi.org/10.1016/S14733099(20)30190-0

Masniadi, R., Angkasa, M. A. Z., Karmeli, E., \& Esabella, S. (2020). Telaah Kritis Ketahanan Pangan Kabupaten Sumbawa dalam Menghadapi Pandemi Covid-19. Sosial Sciences and Humanities, 1(2), 109-120. https://www.semanticscholar.org/paper/Te laah-Kritis-Ketahanan-Pangan-KabupatenSumbawa-Masniadi-

Angkasa/96a263bec0421c692e06e595fae17 a9f1bd345d7

Miles, Mattew B dan Huberman, A. M. (2009). Manajemen Data dan Metode Analisis dalam Denzin, N.K. \& Lincoln, Y.S. (eds.) Handbook of Qualitative Research. Norman K Denzin Dan Yvonna S. Lincoln, Terjemahan Dariyatno, Dkk. Yogyakarta: Pustaka Pelajar.
Moleong, L. J. (2008). Metodologi Penelitian Kualitatif (Revisi). PT Remaja Rosdakarya Offset.

Muksalmina, M. (2020). Jaga Ketahanan Pangan, Pidie Jaya Godok Qanun LP2B. Ajnn.Net. https://www.ajnn.net/news/jaga-

ketahanan-pangan-pidie-jaya-godok-qanunlp2b/index.html

Muqoyyidin, A. W. (2013). Pemekaran wilayah dan otonomi daerah pasca reformasi di Indonesia: Konsep, Fakta Empiris dan Rekomendasi ke Depan. Jurnal Konstitusi, 10(2), 287-310.

Nasution, D. A. D., Erlina, E., \& Muda, I. (2020). Dampak Pandemi Covid-19 Terhadap Perekonomian Indonesia. Jurnal Benefita, 5(2), 212-224.

Nugroho, R. (2011). Public Policy: Dinamika Kebijakan-Analisis Kebijakan-Manajemen Kebijakan (Edisi keti). PT elex Media Komputindo Kelompok Gramdeia-Jakarta.

Onder, G., Rezza, G., \& Brusaferro, S. (2020). CaseFatality Rate and Characteristics of Patients Dying in Relation to COVID-19 in Italy. JAMA Journal of the American Medical Association, 323(18), 1775-1776. https://doi.org/10.1001/jama.2020.4683

Pemerintah Kab. Aceh Barat. (2020). Bupati Aceh Barat Melakukan Pertemuan Dengan Tim Gerakan Mandiri Pangan Aceh (Gampang). Acehbaratkab.Go.Id. http://acehbaratkab.go.id/berita/kategori/b erita/bupati-aceh-barat-hadiri-pertemuandengan-tim-gerakan-mandiri-pangan-acehgampang

Pemprov Aceh. (2020). Pemerintah Aceh Perkuat Ketahanan Pangan di Masa Pandemi Covid-19. Humas.Acehprov.Go.Id.

https://humas.acehprov.go.id/pemerintahaceh-perkuat-ketahanan-pangan-di-masapandemi-covid-19/

Petatematikindo. (2013). Administrasi Provinsi Aceh. Petatematikindo.Wordpress.Com. https://petatematikindo.wordpress.com/20 13/01/09/administrasi-provinsi-nangroeaceh-darussalam/

Pramono, S. A. D. (2014). Pengaruh Modal Sosial terhadap Kemiskinan Rumah Tangga. JEJAK Journal of Economics and Policy, 7(2), 109120. https://doi.org/10.15294/jejak.v7i1.3596

Purwaningsih, T. (2015). Politik Kekerabatan Dalam Politik Lokal Di Sulawesi Selatan Pada Era Reformasi (Studi Tentang Rekrutmen Politik Pada Partai Golkar, Partai Amanat Nasional Dan Partai Demokrat Sulawesi Selatan Tahun 2009). 1-90.

Rivani, E. (2012). Determination of the Dimensions and Indicators of Food Security in Indonesia: 
Syahnaz Oriza Keumala, Eko Priyo Purnomo, Suswanta, Paisal Akbar, Aceh Provincial Government's Food Security Policy to Facing Covid-19 Pandemic

the National Food Security Board-World Food Program Methodology Revisited. Widyariset, 15(1), 151-162.

rri.co.id. (2020). Pemkab Aceh Barat Gunakan Strategi "Gampang" Untuk Katahanan Pangan. Rri.Co.Id. https://rri.co.id/meulaboh/daerah/874763 /pemkab-aceh-barat-gunakan-strategigampang-untuk-katahananpangan?utm_source=news_main\&utm_medi um=internal_link\&utm_campaign=General Campaign

Saliem, H. P., Rachman, \& Ariani, M. (2016). Ketahanan Pangan, Konsep, Pengukuran dan Strategi. Repository.Pertanian.Go.Id, 20(1), 12. https://doi.org/10.21082/fae.v20n1.2002.1 2-24

Satgas Penanganan Covid-19. (2020). Situasi Covid19 di Indonesia. Satgas Penanganan Covid-19. https://experience.arcgis.com/experience/5 7237ebe9c5b4b1caa1b93e79c920338

Schaar, R. M. A. van der. (2017). Penduduk Indonesia. Https://Www.IndonesiaInvestments. Com.

Serambinews.com. (2020). 90 Persen Masyarakat Jalankan Program Ketahanan Pangan. Aceh.Tribunnews.Com. https://aceh.tribunnews.com/2020/08/11/ 90-persen-masyarakat-jalankan-programketahanan-pangan

Setiyadi, A. (2020). Antisipasi Resesi Ekonomi, Pemprov Bikin Program Aceh Mandiri Pangan.
DetikNews.

https://news.detik.com/berita/d5112423/antisipasi-resesi-ekonomipemprov-bikin-program-aceh-mandiripangan.

Suryana, A. (2014). Menuju Ketahanan Pangan Indonesia Berkelanjutan 2025: Tantangan dan Penanganannya Toward Sustainable Indonesian Food Security 2025: Challenges and Its Responses. Forum Penelitian Agro Ekonomi, 32(2), 123-135.

Usmaliadanti, C. (2011). Analisis Pengaruh Tingkat Kemiskinan, Pengeluaran Pemerintah Sektor Pendidikan Dan Kesehatan terhadap Indeks Pembangunan Manusia Di Provinsi Jawa Tengah Tahun 2007-2009. In Journal of Economics Undip Repository (Vol. 2, Issue 1).

Wibowo, E. T. (2020). Pembangunan Ekonomi Pertanian Digital Dalam Mendukung Ketahanan Pangan ( Studi di Kabupaten Sleman: Dinas Pertanian, Pangan, dan Perikanan, Daerah Istimewa Yogyakarta ). Jurnal Ketahanan Nasional, 26(2), 204-228.

Wulandari, W., Suranto, \& Priyo Purnomo, E. (2019). Collaborative Government dalam Mewujudkan Inovasi Pelayanan. JIP (Jurnal Ilmu Pemerintahan): Kajian Ilmu Pemerintahan Dan Politik Daerah, 4(1), 1328. https://doi.org/10.24905/jip.4.1.2019.1328. 